\title{
IMPLEMENTASI PENDEKATAN PEMBELAJARAN BERBASIS TANTANGAN \\ UNTUK MENINGKATKAN PEMAHAMAN KONSEP DAN KETERAMPILAN GENERIK SAINS SISWA SMP PADA TEMA PEMANASAN GLOBAL
}

\author{
Rahmat Hidayat \\ email: rahmat_hidayat@yahoo.com \\ Guru SMP Negeri Kota Bandung
}

\begin{abstract}
ABSTRAK
Penelitian ini bertujuan untuk mendapatkan gambaran dan informasi bagaimana implementasi pendekatan pembelajaran berbasis tantangan untuk meningkatkan keterampilan generik sains dan pemahaman konsep IPA pada tema pemanasan global. Metode penelitian yang digunakan adalah pre-eksperiment dengan desain One Group Pretest-Postest. Subjek penelitian adalah siswa kelas VII dengan jumlah siswa 31 orang di salah satu SMP Negeri di Kab. Bandung Barat Propinsi Jawa Barat. Instrumen penelitian yang digunakan adalah lembar observasi keterlaksanaan pembelajaran, tes keterampilan generik sains dan tes pemahaman konsep, serta skala sikap. Hasil penelitian menunjukkan bahwa implementasi pendekatan pembelajaran berbasis tantangan pada tema Pemanasan Global dapat meningkatkan pemahaman konsep siswa dan keterampilan generik sains siswa yang ditunjukkan dengan presentase nilai rata-rata gain yang dinormalisasi $<$ g $>$ untuk pemahaman konsep sebesar 0,34 (katagori sedang) dan keterampilan generik sains sebesar $(0,44)$ (katagori sedang). Dan hasil analisis data skala sikap menunjukkan bahwa hampir semua siswa setuju terhadap implementasi pendekatan pembelajaran berbasis tantangan dengan prosentase persetujuan sebesar $(83,49 \%)$. Hasil-hasil ini menunjukkan bahwa implementasi pendekatan pembelajaran berbasis tantangan dapat meningkatkan pemahaman konsep siswa dan keterampilan generik sains siswa.
\end{abstract}

Kata Kunci : pendekatan pembelajaran berbasis tantangan, pemahaman konsep,

keterampilan generik sains, pemanasan global

\begin{abstract}
This study aims to gain a description of information on how the implementation of challenge - based learning approach to improve the generic skills of science and understanding science concepts on the theme of global warming. The method that is used in this research was a pre-experimental with a design of One-group pretestposttest. Meanwhile, the subject of the research was the VII grade as much of 31 students of State Junior High School in the West Bandung Regency, West Java province. Furthermore, the research instrument that is used was an observation sheet of study implementation, generic science skills tests and test understanding of concept, and also the attitude scale. The results showed that the implementation of challenge-based learning approach on the theme of global warming could enhance the students' understanding of concepts and students' generic skills of science as indicated by the percentage of the average value of the normalized gain $\langle g>$ for understanding the concept was 0.34 (medium category) and skills generic science was (0.44) (medium category). And the results from the data analysis of attitude scale showed that almost all students were acceptance of a challenge-based learning approach with the approval of the percentage (83.49\%). These results indicated that the implementation of the challenge-based learning approach also could improve students' understanding of concepts and generic skills science of students.
\end{abstract}

Keywords: challenge-based learning approach, understanding of concepts, generic science skills, global warming

\section{PENDAHULUAN}

Selamaini masyarakat dan praktisipendidikan menganggap bahwa indikator keberhasilan pembelajaran sebagai inti proses pendidikan adalah nilai ujian nasional (UN). Pandangan seperti itu tidak keliru, akan tetapi baru melihat salah satu indikator saja. Apabila keberhasilan hanya dipandang dari indikator itu, maka pembelajaran cenderung lebih menekankan kepada aspek kognitif semata, sehingga aspek afektif dan psikomotorik agak terabaikan.

Proses pembelajaran yang menge-depankan proses dan produk akan lebih baik 
dibandingkan dengan mengandalkan hasil akhir saja, disamping pada peserta didik melatih keterampilan berpikir untuk dapat menyelesaikan masalah yang berkaitan dengan kehidupan sehari-hari juga akan lebih tertanam rasa percaya diri untuk menghadapi tantangan hidup. Untuk memberikan keterampilan yang cukup untuk peserta didik dalam menghadapi tantangan hidup diperlukan metode,model, atau pendekatan yang dapat membantu peserta didik mengarahkan pada tujuan tadi, diantaranya guru harus berani mengubah pendekatan ataupun metode biasa yang selama ini dipraktekkan.

Perlunya guru IPA mempersiapkan diri untuk menyelesaikan masalah dalam kehidupan sehari-hari juga ditegaskan oleh National Science Teachers Association/NSTA \& AETS (2003). NSTA \& AETS (dalam Ramlawati 2012) menegaskan standar penyiapan guru IPA bahwa guru IPA pada berbagai level harus menggunakan pendekatan sains untuk menganalisis dan menyelesaikan masalah melalui penyelidikan. Mereka harus memahami bagaimana ilmu pengetahuan mempengaruhi komunitas dan kehidupan mereka. Salah satu keterampilan yang penting pada pembelajaran sains adalah keterampilan generik sains, menurut Brotosiswoyo (2001) menyatakan bahwa keterampilan generik sains saat ini sangat penting dalam membangun kepribadian dan pola tindakan dalam kehidupan setiap insan Indonesia. Hal ini disebabkan karena keterampilan generik sains merupakan dasar dalam proses pengambilan keputusan dan pemecahan masalah dalam kehidupan sehari-hari yang melibatkan siswa. Pentingnya keterampilan generik sains diakui oleh beberapa peneliti sebelumnya (Harris et al., 2007; Mitchell, 2005; dan Brotosiswoyo, 2001).

Berdasarkan studi pendahuluan yang dilakukan oleh penulis disekolah diperoleh hasil bahwa pembelajaran yang dilakukan dengan metode konvensional terutama materi IPA Terpadu masih terpusat oleh guru, materi yang diberikan masih terpisah, materi pelajaran masih dibahas dari satu disiplin tertentu tidak dibahas secara multi disiplin IPA baik dari segi disiplin Ilmu Fisika, Biologi dan Kimia sedangkan IPA itu sendiri merupakan satu kesatuan disiplin ilmu yang tidak bisa dipisahkan atau terintegrasi satu sama lainnya. Hal inilah yang menyebabkan materi IPA tidak sepenuhnya terserap oleh siswa dan menjadi pembelajaran yang bermakna dalam proses pembelajaran di sekolah.

Dampak dari permasalahan diatas menyebabkan pemahaman konsep siswa rendah, begitu pula dengan keterampilan generik sains siswa yang dimiliki siswa sangatlah kurang, diperkuat dengan hasil diskusi dengan guru IPA mengenai hasil ulangan harian rata-rata siswa 52\% masih dibawah KKM yaitu 65\%. Pada saat proses pembelajaran siswa tidak ikut dilibatkan maka hal ini menyebabkan keterampilan yang harus dimiliki siswa tidak dapat terukur dengan baik, guru hanya melihat dari satu aspek kognitif saja tidak melihat dari segi yang lainnya yaitu aspek keterampilan/ psikomotor. Apalagi saat ini pada kurikulum 2013 sudah ditetapkan 4 aspek yang harus diterapkan pada siswa antara lain: aspek sikap, sosial, pengetahuan dan keterampilan harus muncul pada diri siswa, dan standar proses pembelajaran selama ini belum menggambarkan urutan pembelajaran yang rinci sehingga membuka peluang penafsiran yang beraneka ragam dan berujung pada pembelajaran yang berpusat pada guru.

Terkait dengan permasalahan pembel-ajaran diatas, peneliti merasa perlu adanya inovasi dalam proses pembelajaran IPA. Salah satu pendekatan yang dapat melibatkan siswa dalam pembelajaran adalah melalui pendekatan pembelajaran berbasis tantangan (Challenge Based Learning), pembelajaran berbasis tantangan ini merupakan sebuah pendekatan dalam pembelajaran dimana 
pembelajaran dimulai dari fenomena atau kejadian yang akrab dalam kehidupan kita sehari-hari (kontekstual) maupun berasal dari permasalahan yang ada atau isu-isu global, dan untuk memecahkan masalah atau tantangan tersebut dilakukan sebuah perencanaan untuk menyelesaikannya. Tantangan yang diajukan dapat berupa tugas menyelesaikan masalah, tugas menjelaskan fenomena alam, atau berupa proyek membuat prakarya dengan menggunakan konsep dasar IPA yang dipelajari (Yalcin, 2009 dalam setiawati 2013)

Tema atau ide yang dipilih untuk dibahas pada pembelajaran ini adalah pemanasan global (global warming) dengan alasan bahwa tema atau ide tentang pemanasan global sangat akrab diperbincangkan dan termasuk fenomena yang sedang dan akan terjadi pada masa yang akan datang. Hal ini disebabkan pemanasan global yang terjadi diseluruh dunia seperti dampak dari transportasi kendaraan, pabrik-pabrik industri telah memberi kontribusi bagi terjadinya pemanasan global. Pada pendekatan pembelajaran Berbasis Tantangan ini terdapat keterkaitan keterampilan yang dimunculkan dengan keterampilan generik sains siswa berdasarkan indikator-indikator yang terdapat pada keterampilan generik sains, diantaranya indikator bahasa simbolik, sampai kepada abstraksi sehingga diharapkan pendekatan pembelajaran berbasis tantangan ini mampu meningkatkan keterampilan generik sains siswa.

Berdasarkan latar belakang diatas, maka peneliti mencoba untuk menerapkan pembelajaran berbasis tantangan untuk tema pemanasan global (global warming) dengan tujuan untuk meningkatkan pemahaman konsep dan keterampilan generik sains siswa.

\section{METODE PENELITIAN}

Penelitian ini menggunakan metode Preexperiment (Milla, Mc. JH., Schumacher, Sally. 1997, Fraenkel \& Wallen, 2006). Dalam penelitian ini peneliti hanya ingin melihat gambaran dan informasi dari implementasi pendekatan pembelajaran berbasis tantangan terhadap peningkatan pemahaman konsep dan keterampilan generik sains siswa, tidak sampai pada pengujian efektivitasnya jika dibandingkan dengan penggunaan model pembelajaran yang lain. Metode ini merupakan metode penelitian eksperimen tetapi tanpa penggunaan kelompok kontrol. Perlakuan hanya difokuskan pada satu kelompok saja dengan bentuk rancangan penelitian one group pretest-posttest yaitu penelitian yang dilaksanakan pada satu kelompok tanpa menggunakan kelas kontrol

Penelitian dilakukan pada kelas VII pada salah satu SMP Negeri yang terletak di Kabupaten Bandung Barat pada tahun pembelajaran 2013/2014. Sampel penelitian diambil satu kelas secara acak. Teknik sampling yang digunakan adalah dengan mengundi seluruh kelas populasi yang memiliki kemampuan yang setara tanpa mengacak siswa tiap kelasnya

\section{HASIL DAN PEMBAHASAN}

\section{Keterlaksanaan Pembelajaran Berbasis Tantangan}

Keterlaksanaan kegiatan pendekatan pembelajaran berbasis tantangan berdasarkan aktifitas guru pada tema pemanasan global diamati oleh seorang observer setiap pertemuannya. Pengamatan dilakukan menggunakan lembar pengamatan aktifitas guru dengan skala penilaian kriteria ya atau tidak. Setiap aspek yang diamati muncul dalam pembelajaran di kelas diberi skor 1 dan aspek yang tidak muncul diberi skor nol (0).

Persentase keterlaksanaan pembel-ajaran berdasarkanaktifitas guru dalamimplementasi pembelajaran berbasis tantangan pada tema Pemanasan Global yang dihimpun dari observer ditunjukkan pada tabel1 
Tabel 1

Persentase Keterlaksanaan Pembelajaran Berbasis Tantangan

\begin{tabular}{|c|c|c|}
\hline Pertemuan & $\begin{array}{c}\text { Persentase keterlaksanaan } \\
(\%)\end{array}$ & Kriteria \\
\hline 1 & $80 \%$ & Hampir seluruh kegiatan terlaksana \\
\hline 2 & $100 \%$ & Seluruh kegiatan terlaksana \\
\hline
\end{tabular}

Berdasarkan tabel 1, dapat dilihat bahwa guru dapat melaksanakan pembelajaran sesuai dengan rencana. Persentase keterlaksanaannya mencapai $90 \%$ dengan kriteria seluruh kegiatan terlaksana, artinya setiap tahapan pembelajaran dapat terlaksana dan dilakukan dengan baik. Meskipun ada catatan yang ditulis oleh pengamat diantaranya guru dalam kegiatan diskusi siswa guru terlalu terburu-buru dalam menginstruksikan dan mengingatkan siswa dalam pengerjaan tugas diskusi.

\section{Peningkatan Pemahaman Konsep Secara Umum}

Dari penelitian yang telah dilaksanakan diperoleh data hasil pretest dan posttest tentang pemahaman konsep siswa. Berdasarkan data tersebut kemudian diperoleh rata-rata pretest dan posttestnya dan diperoleh peningkatan pemahaman konsep siswa melalui perhitungan rata-rata gain yang dinormalisasi $<\mathrm{g}>$.

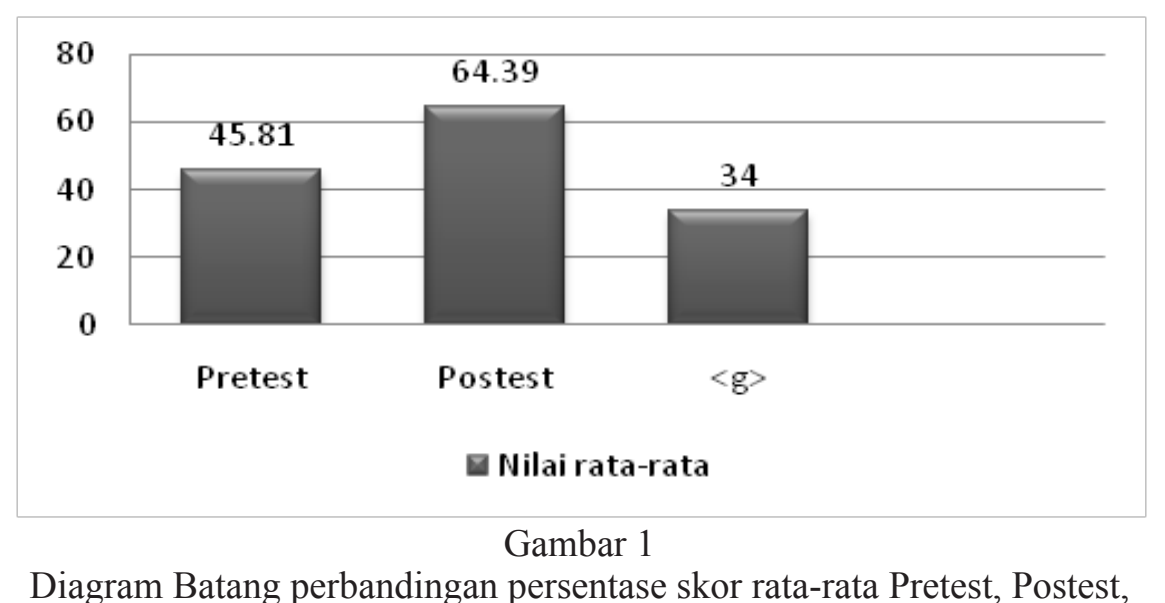

Diagram Batang perbandingan persentase skor rata-rata Pretest, Postest, dan gain Pemahaman Konsep Siswa

Gambar 1, di atas menunjukkan rata-rata skor prestest mencapai rata-rata 45,81\%, sementara itu, hasil posttest pemahaman konsep siswa memperlihatkan adanya kenaikan skor rata-rata menjadi sebesar $64,39 \%$ dan rata-rata gain yang dinormalisasi $<$ g $>$ pemahaman konsep siswa sebesar 34 $\%$. Rata-rata gain yang dinormalisasi $<$ g $>$ termasuk pada kategori sedang. Hal ini menunjukkan bahwa pemahaman konsep pada materi pemanasan global di kelas VII meningkat dengan kategori sedang setelah implementasi pendekatan pembelajaran berbasis tantangan.

Untuk mengetahui peningkatan n-gain dari pemahaman konsep selanjutnya menggunakan uji statistik menggunakan teknik parametrik, yaitu uji $t$.

Hipotesis yang digunakan pada Uji statistik perbedaan dua rata-rata pretes dan Postest Pemahaman konsep (Uji t)

Ho : diterima jika sig $>0,05$ atau $\mathrm{H}_{0}$ : diterima jika $-\mathrm{t}_{(1-1 / 2 \alpha)}<\mathrm{t}<\mathrm{t}_{(1-1 / 2 \alpha)}$, harga $\mathrm{t}_{(1-}$ $1 / 2 \alpha)$ diperoleh dari daftar distribusi t dengan peluang $(1-1 / 2 \alpha)$, sebaliknya $H_{o}$ ditolak pada harga lainnya.

H1: ditolak jika nilai sig. $>0,05$, Taraf signifikansi uji $\alpha=0,05$

Ho: Tidak terdapat perbedaan rata-rata nilai pretes dan nilai postes Pemahaman Konsep. 
H1: terdapat perbedaan rata-rata nilai pretes dan nilai postes Pemahaman Konsep

Dari kolom uji t menunjukan bahwa nilai $\mathrm{p}=$ 0,000 untuk uji 2-ekor. Karena P-value lebih kecil dari $\alpha=0,05$ yang berarti $\mathrm{H}_{1}$ diterima, sehingga dapat kita simpulkan bahwa secara statistik terdapat perbedaan yang bermakna rata-rata nilai pretes dengan nilai postest pemahaman konsep siswa

Pada harga $t_{(0,975)}$ untuk uji dua sisi pada distribusi student $(\mathrm{dk})=60$ diperoleh $\mathrm{t}_{\text {tabel }}$ $=2,000$. Dari hasil perhitungan $\mathrm{t}=12,56$ berada pada daerah penolakan $\mathrm{H}_{\mathrm{o}}$, maka disimpulkan terdapat perbedaan yang bermakna rata-rata nilai pretes dengan nilai postest pemahaman konsep siswa, Secara lengkap, kita dapat menyimpulkan bahwa pendekatan pembelajaran berbasis tantangan secara nyata dapat meningkatkan pemahaman konsep siswa.

\section{Peningkatan Profil Pemahaman Konsep}

Peningkatan Profil Pemahaman Konsep untuk melihat perbandingan perolehan ratarata skor pretest dan posttest pada setiap indikator tersaji pada gambar 2 .

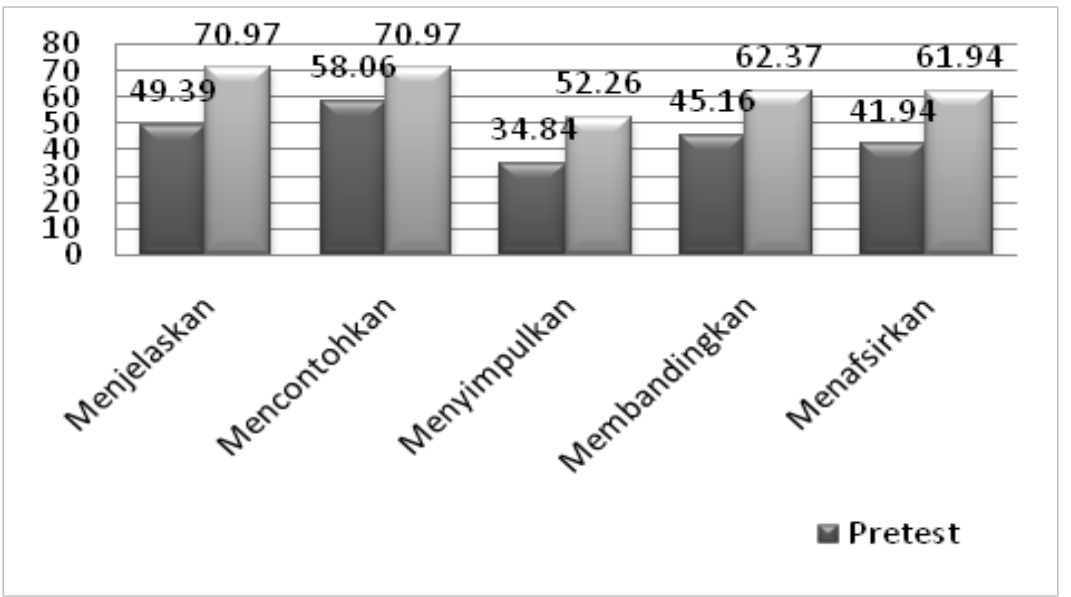

Gambar 2, Diagram batang perbandingan rata-rata pretest, rata-rata posttest profil indikator pemahaman konsep

Gambar 2, menunjukkan rata-rata pretest pemahaman konsep pada setiap indikator antara lain: indikator menjelaskan 49,39 $\%$, indikator mencontohkan 58,06\%, indikator menyimpulkan $34,84 \%$, indikator membandingkan $45,16 \%$, dan indikator menafsirkan $41,94 \%$. Sedangkan rata- rata posttest pemahaman konsep siswa pada indikator menjelaskan 70,97 \%, indikator mencontohkan 70,97 \%, indikator menyimpulkan 52,26\%, indikator membandingkan $62,37 \%$, dan indikator menafsirkan $61,94 \%$.

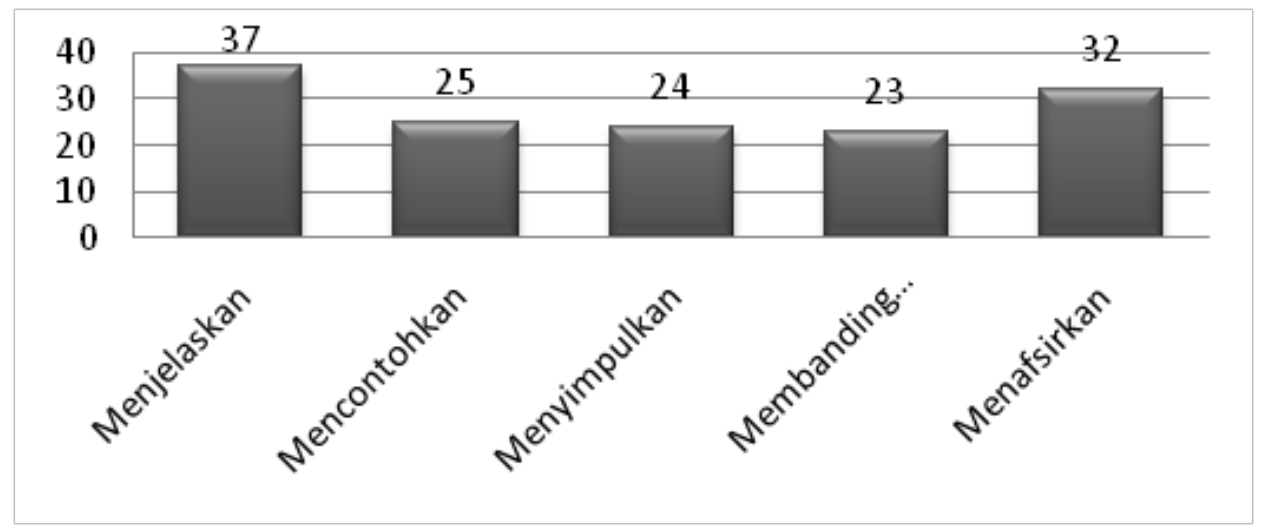

Gambar 1.3 Diagram batang rata-rata gain $<\mathrm{g}>$ setiap indikator pemahaman konsep 
Gambar 3, menunjukkan bahwa rata-rata gain dinormalisasi $<\mathrm{g}>$ yang tertinggi pada indikator menjelaskan yaitu sebesar $37 \%$ dan terendah pada indikator membandingkan sebesar $23 \%$.

Peningkatan pemahaman konsep siswa pada kelima indikator berdasarkan kriteria gain yang dinormalisasi <g> (Metzer, 2002) dihasilkan dengan kategori sedang pada indikator menjelaskan dan menafsirkan sedangkan kategori rendah terdapat pada indikator mencontohkan, membandingkan dan menyimpulkan. rata-rata secara umum pada tiap indikator tersebut jika dilihat dari gain yang dinormalisasi rata-rata 34\% ini menunjukkan bahwa pemahaman konsep siswa mengalami peningkatan setelah implementasi pendekatan pembelajaran berbasis tantangan.

Indikator yang tertinggi yaitu menjelaskan karena indikator-indikator tersebut secara langsung sering dilatihkan yaitu pada saat pembelajaran diskusi dan Tanya jawab. Lain halnya dengan indikator menafsirkan yang lebih tinggi dibanding dengan menyimpulkan, hal ini disebabkan karena ketika pembelajaran siswa lebih banyak diarahkan dan dilatih pada berbagai aktivitas yang menunjang kemampuan menafsirkan seperti berlatih menerjemahkan gambar, cara membaca grafik, memprediksi suatu kejadian dan menafsirkan data-data dari tabel ke dalam bentuk kalimat.
Sementara itu, peningkatan pemahaman konsep menyimpulkan lebih rendah dibanding menafsirkan hal ini disebabkan karena walaupun pembelajaran tantangan ini telah memfasilitasi dan melatih siswa untuk menjelaskan hasil diskusinya sehingga siswa punya alasan ilmiah untuk menyangkal, membenarkan dan membuat kesimpulan. Namun secara keseluruhannya pelaksanaanya masih kurang baik. Pada tahap akhir pembelajaran, pada saat guru memberikan kesempatan untuk menyimpulkan pada proses pembelajaran hanya sedikit saja siswa yang mampu menyimpulkan hal ini terlihat pada pengisian LKS yang diberikan guru. Sebagian besar siswa menuliskan suatu kesimpulan adalah dengan menuliskan informasi dari bacaan yang ada di LKS bukan dari hasil pemikirannya sendiri. Kurang maksimalnya pencapaian skor rata-rata $\mathrm{N}$-gain pemahaman kesimpulan ini kemungkinan juga disebabkan karena jumlah soal yang digunakan relatife sedikit sehingga hasil yang diperoleh tidak dapat digeneralisasi lebih jauh.

Berdasarkan hasil analisis dan pembahasan dapat disimpulkan bahwa implementasi pembelajaran tantangan yang diawali dengan menyajikan ide besar berupa fenomena pemanasan global melalui tugas/proyek dapat meningkatkan pemahaman konsep. Hal tersebut sesuai dengan pendapat Drost, S.J (Yuniaritha, 2013) yang mengungkapkan bahwa salah satu cara meningkatkan

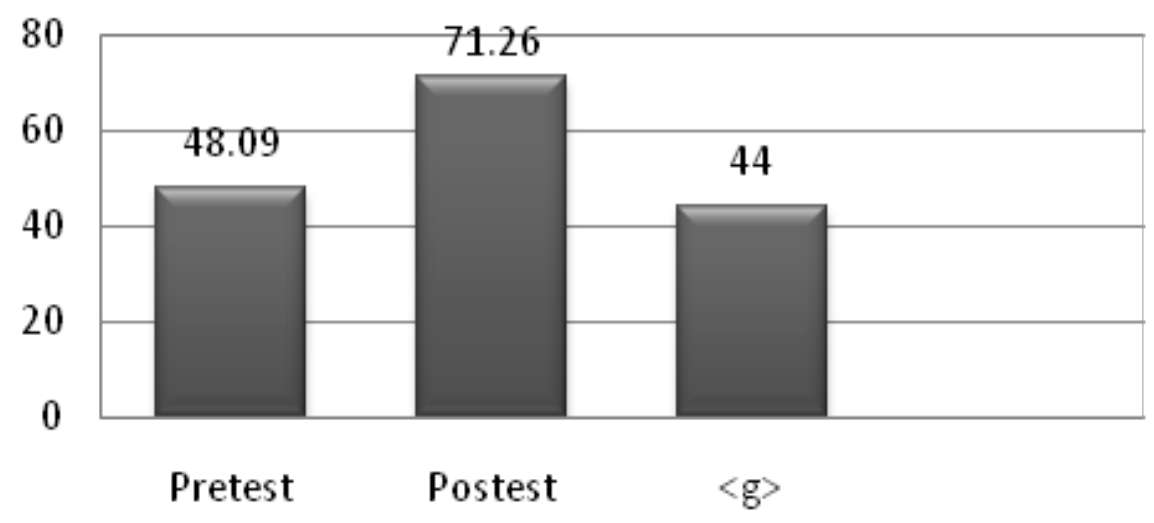

Gambar 4 Diagram batang rata-rata prestest, rata-rata posttest, dan rata-rata gain yang dinormalisasi $<\mathrm{g}>$ keterampilan generik sains 
pemahaman konsep siswa dari berbagai ide mengenai pembelajran IPA adalah kegiatan anak di kelas diantisipasi menjadi serupa dengan apa yang sesungguhnya dilakukan para ilmuwan dalam percobaan mereka, namun dalam situasi yang berbeda.

\section{Peningkatan Keterampilan Generik Sains Siswa Secara Umum}

Deskripsi data keterampilan generik sains siswa siswa SMP pada tema Pemanasan Global berdasarkan pengolahan data tes keterampilan generik sains seperti pada gambar 4.

Skor prestest mencapai rata-rata $48.09 \%$, sementara itu, hasil posttest keterampilan generik sains siswa memperlihatkan adanya kenaikan skor rata-rata menjadi sebesar 71.26 $\%$ dan rata-rata gain yang dinormalisasi $<\mathrm{g}>$ keterampilan generik sains siswa sebesar $44 \%$. Rata-rata gain yang dinormalisasi $<\mathrm{g}>$ termasuk pada kategori sedang. Hal ini menunjukkan bahwa keterampilan generik sains pada materi pemanasan global di kelas VII meningkat dengan kategori sedang setelah implementasi pendekatan pembelajaran berbasis tantangan. Maka untuk selanjutnya pengujian hipotesis menggunakan teknik parametrik, yaitu uji $t$.

Uji statistik perbedaan dua rata-rata pretes dan Postest keterampilan Generik sains (Uji t)

Ho: diterima jika sig $>0,05$ atau $\mathrm{H}_{0}$ : diterima jika $-\mathrm{t}_{(1-1 / 2 \alpha)}<\mathrm{t}<\mathrm{t}_{(1-1 / 2 \alpha)}$, harga $\mathrm{t}_{(1-1 / 2 \alpha)}$ diperoleh dari daftar distribusi $t$ dengan peluang $(1-1 / 2 \alpha)$, sebaliknya $H_{o}$ ditolak pada harga lainnya.

H1: ditolak jika nilai sig. $>0,05$, Taraf signifikansi uji $\alpha=0,05$

Ho: Tidak terdapat perbedaan rata-rata nilai

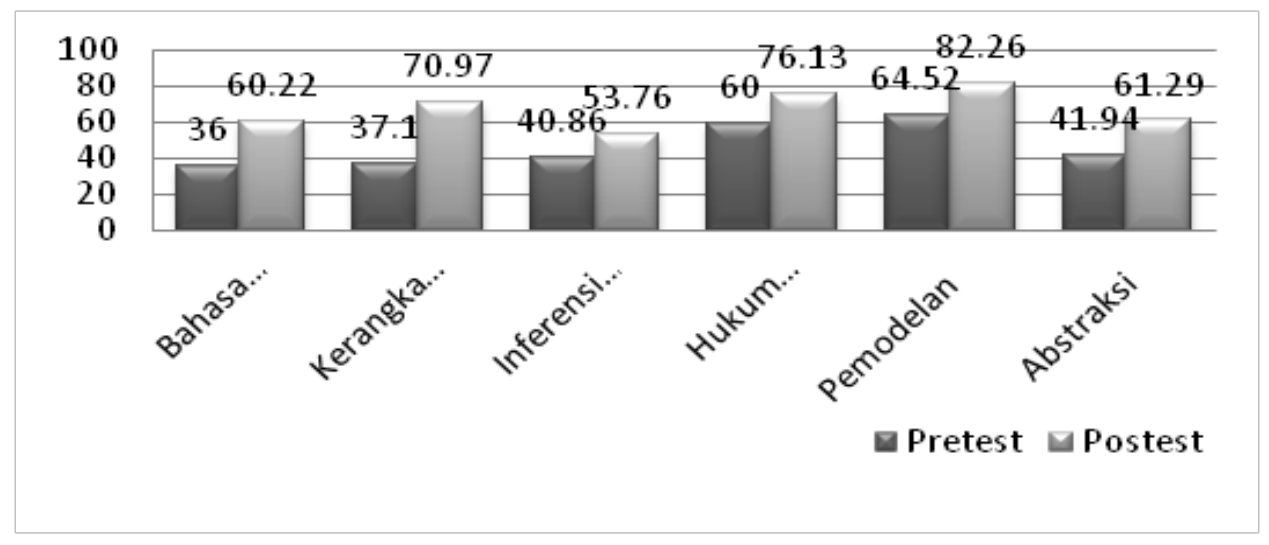

Gambar 5 Diagram batang perbandingan rata-rata pretest, rata-rata posttest profil indikator keterampilan generik sains

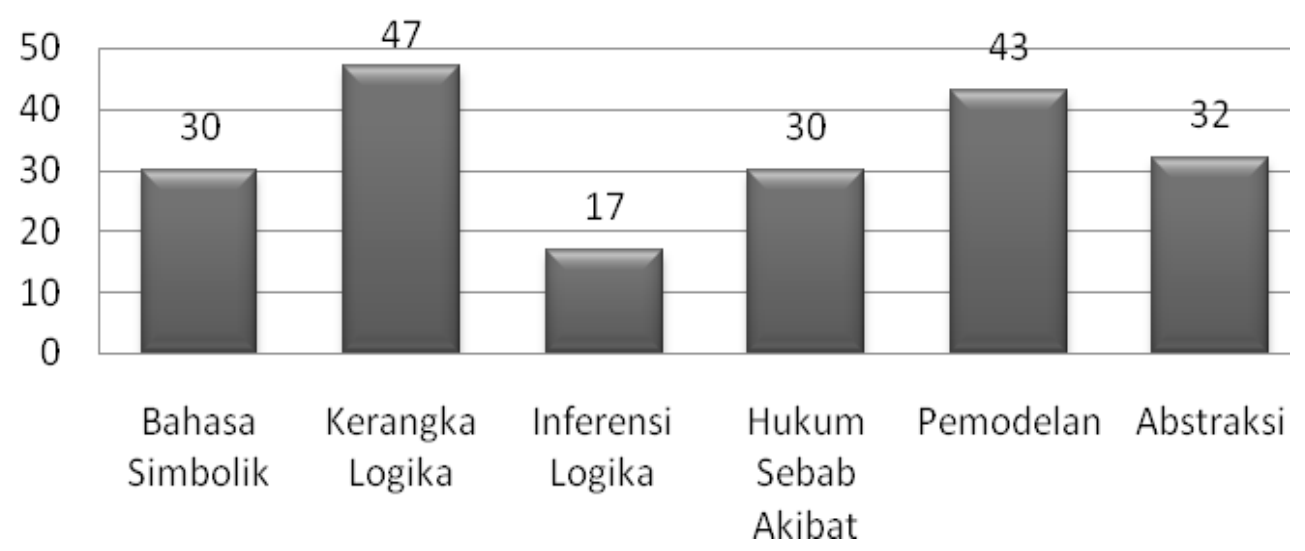

Gambar 6 Diagram batang rata-rata gain $<\mathrm{g}>$ Profil keterampilan Generik Sains 
pretes dan nilai postes keterampilan generik sains.

H1: terdapat perbedaan rata-rata nilai pretes dan nilai postes keterampilan generik sains.

Dari kolom uji t menunjukkan bahwa nilai $\mathrm{p}=$ 0,000 untuk uji 2-ekor. Karena P-value lebih kecil dari $\alpha=0,05$ yang berarti $\mathrm{H}_{1}$ diterima, sehingga dapat kita simpulkan bahwa secara statistik terdapat perbedaan yang bermakna rata-rata nilai pretes dengan nilai postest keterampilan generik sains siswa, Pada harga $\mathrm{t}_{(0,975)}$ untuk uji dua sisi pada distribusi student $(\mathrm{dk})=60$ diperoleh $\mathrm{t}_{\text {tabel }}=2,000$. Dari hasil perhitungan $\mathrm{t}=18,492$ berada pada daerah penolakan $\mathrm{H}_{\mathrm{o}}$, maka disimpulkan terdapat perbedaan yang bermakna rata-rata nilai pretes dengan nilai postest keterampilan generik sains siswa

Secara lengkap, kita dapat menyimpulkan bahwa pendekatan pembelajaran berbasis tantangan secara nyata dapat meningkatkan keterampilan generik sains siswa.

\section{Peningkatan Profil Keterampilan Generik Sains Siswa}

Indikator Keterampilan generik sain yang digunakan antara lain : (1) bahasa simbolik, (2) kerangka logika, (3) inferensi logika, (4) hukum sebab akibat, (5) pemodelan, dan (6) abstraksi. Berikut adalah rata-rata skor pretest dan posttest pada setiap indikator

Gambar 5, menunjukkan rata-rata pretest dan posttest keterampilan generik sains pada setiap indikator antara lain: indikator bahasa simbolik $36 \%$ menjadi $60,22 \%$, indikator kerangka logika 37,1 \% menjadi 70,97\%, indikator inferensi logika 40,86\% menjadi $53,76 \%$, indikator hukum sebab akibat $60 \%$ menjadi $76,13 \%$, indikator pemodelan $64,52 \%$ menjadi $82,26 \%$ dan indikator abstraksi 41,94\% menjadi 61,29\%.

Dari gambar 6 menunjukkan bahwa rata-rata gain dinormalisasi $<\mathrm{g}>$ yang tertinggi pada indikator kerangka logika $47 \%$ dan terendah pada indikator inferensi logika sebesar $17 \%$.

Peningkatan keterampilan generik sains siswa pada keenam indikator berdasarkan kriteria gain yang dinormalisasi $<\mathrm{g}>$ (Metzer, 2002) dihasilkan dengan kategori sedang pada indikator bahasa simbolik, kerangka logika, hukum sebab akibat, pemodelan dan abstraksi sedangkan kategori rendah terdapat pada indikator inferensi logika. Rata-rata secara umum pada tiap indikator tersebut jika dilihat dari gain yang dinormalisasi ratarata $44 \%$ kategori sedang. ini menunjukkan bahwa keterampilan generik sains siswa mengalami peningkatan setelah implementasi pendekatan pembelajaran berbasis tantangan.

Peningkatan ini terkait dengan integrasi indikator tersebut pada beberapa tugas dalam pembelajaran. Yang paling rendah adalah indikator inferensi logika $(0,17)$ dengan indikator yang dikembangkan mengajukan prediksi gejala alam/fenomena alam yang belum terjadi berdasarkan fakta terdahulu dan menarik kesimpulan dari suatu gejala/ fenomena berdasarkan aturan/hukumhukum terdahulu. Kesimpulan yang ditarik dapat berupa penjelasan atau interpretasi dari hasil suatu observasi atau suatu kajian atau berupa kesimpulan terhadap persoalan baru sebagai akibat logis dari kesimpulankesimpulan atau teori yang ada, tanpa melihat bagaimana makna kongkret sesungguhnya. (Brotosiswoyo, 2001)

Pada penelitian ini indikator KGS Inferensi logika dikembangkan melalui indikator seperti Mengajukan prediksi terhadap peristiwa pemanasan global, menarik kesimpulan dari suatu fenomena berdasarkan aturan dan Menginterpretasikan grafik tentang peningkatan suhu rata-rata bumi setiap tahun.

Dalam hal ini siswa belum tergali dan terbiasa dalam memprediksi suatu kejadian dan membutuhkan pemikiran yang tinggi karena fakta-fakta yang dihadirkan belum bisa dijadikan faktor yang bisa menguatkan 
prediksi gejala alam seperti halnya pada peristiwa pemanasan global.

\section{Tanggapan siswa terhadap pelaksanaan pembelajaran berbasis tantangan}

Pada akhir pembelajaran siswa diberikan skala sikap yang berisi pernyataan-pernyataan tentang pelaksanaan pembelajaran berbasis tantangan pada tema pemanasan global. Skala sikap ini bertujuan untuk mengetahui tanggapan siswa terhadap implementasi pembelajaran berbasis tantangan pada tema pemanasan global. Dan hasil analisis data skala sikap menunjukkan bahwa hampir semua siswa setuju terhadap implementasi pendekatan pembelajaran berbasis tantangan dengan prosentase persetujuan sebesar $(83,49 \%)$. Hasil ini menunjukkan bahwa implementasi pendekatan pembelajaran berbasis tantangan dapat meningkatkan pemahaman konsep siswa dan keterampilan generik sains siswa.

\section{KESIMPULAN}

Berdasarkan hasil penelitian yang telah dilakukan dapat disimpulkan bahwa implementasi pendekatan pembelajaran berbasis tantangan dapat meningkatkan pemahaman konsep dan keterampilan generik sains siswa. Signifikansi ini ditunjukkan baik secara keseluruhan maupun pada setiap profil indikator pemahaman konsep dan keterampilan generik sains siswa.

Tanggapan siswa terhadap imple-mentasi pendekatan pembelajaran berbasis tantangan pada tema pemanasan global memberikan tanggapan yang positif dan setuju apabila dilaksanakan dalam proses pembelajaran. Pemberian tugas berupa tantangan dan kegiatan diskusi perlu dilakukan dalam setiap pembelajaran karena dapat membantu siswa dalam memahami konsep IPA.

\section{DAFTAR PUSTAKA}

Brotosiswoyo. (2000) Hakikat Pembelajaran Fisika di Perguruan Tinggi. Jakarta: PPUT Dirjen Dikti Depdiknas

Brotosiswoyo. (2001) Hakikat Pembelajaran MIPA dan Kiat Pembelajaran Kimia di Perguruan Tinggi. Jakarta: PAU-PPAI

Fraenkel, J.R \& Wallen, N.E. (1932) How To Design And Evaluate Research In Education. McGraw- Hill International. United State of America

Milla, Mc. JH., Schumacher, Sally. (1997) Research In Education. New York San Fransisco: Addison Wesley Longman. Inc

Ramlawati. (2012) Pengembangan Model Asesmen Portofolio Elektronik (APE) Untuk Meningkatkan Keterampilan Generik Sains Mahasiswa Pada Praktikum Kimia Anorganik. Disertasi Doktor Ilmu Pendidikan. Bandung: SPs UPI. Tidak diterbitkan

Setiawati, I. (2013). Penerapan Model Pembelajaran Fisika Berbasis Proyek Untuk Meningkatkan Pemahaman Konsep Dan Keterampilan Pemecahan Masalah. Tesis. Bandung: SPs UPI. Tidak diterbitkan 